УДК 636.4.082

\title{
ПОШУК ОПТИМІЗОВАНИХ РІШЕНЬ ПРИ РОЗРОБЦІ ПРОЕКТУ 3 ВИРОБНИЦТВА ПРОДУКЦІЇ СВИНАРСТВА ПОТУЖНІСТЮ 24 ТИС. ГОЛІВ У РІК
}

\author{
Волощук Василь Михайлович \\ доктор сільськогосподарських наук, професор, член-корр. НААН \\ Інститут свинарства і агропромислового виробництва НААН \\ ORCID: 0000-0001-6980-1293 \\ E-mail: pigbreeding@ukr.net \\ Смислов Сергій Юрійович \\ кандидат сільськогосподарських наук \\ Інститут свинарства і агропромислового виробництва НААН \\ ORCID: 0000-0002-8956-7753 \\ E-mail: pigmon@ukr.net \\ Підтереба Михайло Олексійович \\ аспірант \\ Інститут свинарства і агропромислового виробництва НАAН \\ ORCID: 0000-0002-5592-3799 \\ E-mail: M.Pidtereba@gmai.com \\ Підтереба Олексій Іванович \\ кандидат біол. наук, старший науковий співробітник \\ Інститут свинарства і агропромислового виробництва НААН \\ ORCID: 0000-0001-7434-9094 \\ E-mail: $\underline{\text { O.Pidtereba@gmai.com }}$
}

\author{
Хмельничий Леонтій Михайлович \\ доктор сільськогосподарських наук, професор \\ Сумський національний аграрний університет \\ ORCID: 0000-0001-5175-1291 \\ Email: khmelnychy@ukr.net
}

Зниження кількості продукції свинарства на ринку та постійне зростання попиту на неї завжди стимулює інвесторів шукати шляхи нарощування обсягів виробництва товарної свинини. Підвищити зацікавленість інвесторів можна лише оцінивши всі ступені ризиків максимально визначивщи значення параметрів виробничої діяльності і ще до початку активного вкладання коштів вказати на обсяги необхідних інвестицій та параметри прибуткової діяльності. Дослідження з пошуку оптимізованих рішень проводили шляхом комп'ютерного моделювання послідовно змінюючи значення параметрів визначаючи вірогідні зміни показників виробничої діяльності. Встановлено, що при одночасній зміні багатоплідності з 12 до 14 поросят і зменшенні технологічного відходу з 14,3 до 10,7\% при постійній кількості основних свиноматок впродовж року на свинокомплексі потужністю 24 тис. голів у рік кількість приплоду збільшиться на 4 368, а відлучених поросят на 4844 голів, це дозволить передати на дорощування не 21996, а 26728 голів, що і потрібно враховувати при розрахунку необхідної кількості станків для їх розміщення. Залежно від компактності розміщення станкового обладнання, системи гноєвидалення, способу роздавання корму та водонапування відсоток зайнятої станками виробничої площі буде змінюватись, а отже і буде змінюватись потреба у загальній кількості приміщень для утримання поголів'я усіх технологічних груп. При зміні зайнятої станками площі з 70 до 52 відсотків потреба загальної площі зміниться з 4320 до $5760 \mathrm{M}^{2}$, що рівнозначно додатковому приміщенню розмірами 80 х 18 м. Збільшення інтенсивності росту у період дорощування та відгодівлі призводить до зменшення потреби у кількості станків та загальної площі для утримання поголів'я, а також значного зменшення тривалості відгодівлі, що дозволить знизити витрати корму та прискорити оборот станкомісць. Недотримання правил проведення розрахунків та ігнорування змінних значень вхідних даних у кінцевому результаті призводить до порушення роботи створеного комплексу, а також невідповідності між розрахунковим бізнес-планом та реальними даними економічно-господарської діяльності підприємства з виробництва продукції свинарства.

Ключові слова: свинарство, прогнозування, комп'ютерне моделювання, зміна поголів'я, станки, технологічні груnu

DOI: https://doi.org/10.32845/bsnau.lvst.2019.1-2.7

Свинарство завдяки високим біологічним властивостям тварин, як то багатоплідність, відносно короткий період досягнення реалізаційної маси, всеїдність, велика кількість продуктів споживання які виробляються зі свинини, можли- вість давати більше двох опоросів за рік, відіграє значну роль у забезпеченні населення продуктами харчування.

Зниження кількості продукції свинарства на ринку $є$ наслідком зменшення поголів'я свиней в Україні, а постійне 
зростання попиту на неї стимулює інвесторів шукати шляхи нарощування обсягів виробництва товарної свинини.

Збільшення попиту на якісну свинину $є$ наслідком ії високої поживності і необхідності у раціоні людини. Зі спожитої свинини до організму людини транссрормується до $20 \%$ поживних речовин, з курятини лише $5 \%$, а з баранини не більше 4 відсотків. Свинина $€$ незамінним продуктом харчування, тому що максимально збалансована за легкозасвоюваними білками, які містять незамінні амінокислоти, вітаміни та мікроелементи, тому частка свинини у раціоні людей складає близько 40 відсотків.

Підвищення попиту на свинину та продукти ії переробки з одночасним зменшенням її кількості на ринку призводить до стрімкого підвищення як реалізаційної, так і закупівельної вартості свинини у живій чи забійній масі. Підвищення вартості виробленої продукції свинарства сприяє підвищенню економічної доцільності її виробництва, а отже і рентабельності та окупності вкладених інвестицій.

Підвищення прибутковості свинарства породжує зацікавленість інвесторів у вкладанні коштів у розвиток підприємств промислового типу навіть не звертаючи уваги на значні ризики їх вірогідного неповернення.

Чому у пріоритетах інвестування знаходяться саме промислові підприємства з виробництва продукції свинарства? Тому що коефіцієнт корисної дії вкладених інвестицій зростає разом з рівнем рентабельності, який залежить від можливості реалізувати генетичний потенціал тварин і досягнення їх максимальної продуктивності. Генетичний потенціал тварин буде повністю реалізований лише за умови розробки та запровадження передових технологій утримання свиней, повноцінності їх годівлі якісними кормами максимально збалансованими як за поживними речовинами, так і за вітамінним та мінеральним складом.

Створити належні умови мікроклімату з тепловим вирівнюванням повітря у приміщеннях не залежно від пори року, провести якісне очищення повітря від шкідливих газів та різноманітних домішок можна лише при значному інвестуванні, що не під силу дрібним фермам. Також великі комплекси можуть дозволити собі закупити велику кількість тварин з завідомо високими генетичним потенціалом, реалізація якого забезпечить високу швидкість росту та м'ясність туш відгодівельного поголів'я.

Генетичний (16 порід свиней), кормовий, виробничий та технологічний потенціал, дозволяє Україні не лише призупинити падіння виробництва продукції свинарства, а й наростити її до рівня, коли на 1 людину у рік буде не менше 25 кг свинини, та ще й буде можливість експортувати їі, отримуючи непогану валютну виручку.

Матеріали й методи досліджень. Дослідження з пошуку оптимізованих рішень проводилось у межах завдання 30.02.01.12.П. «Розробити комп'ютерні програми для пошуку оптимальних рішень при виборі технологічних параметрів» за наданим технічним завданням «Розробити Проект створення свинокомплексу з замкнутим циклом виробництва потужністю 24000 голів свиней у рік» який планується розмістити у Київській області.

Послідовні розрахунки зміни потреби поголів'я, станкової та загальної площі приміщень, станків та ін. залежно від зоотехнічних та виробничих показників використаних при розробці технології утримання та руху поголів'я проводили 3 урахуванням біологічних особливостей свинопоголів'я, кормової бази господарства, умов утримання і годівлі та системи утримання поголів'я різних технологічних груп.

При проведенні досліджень використано наступні прийоми і методи: зоотехнічні, розрахунково-аналітичні, комп'ютерного моделювання, конструкторські та економічні. При розробці інформаційних систем та їх налаштування використано методичні посібники $[1,2,5,8]$, нормативні дані яких були взяті за основу розробки алгоритму та проведених розрахунків.

При розробці методичних підходів до проведення досліджень по визначенню параметрів потокової системи отримання опоросів та проведення оцінки окремих елементів технологій виробництва продукції свинарства було використано розроблений алгоритм.

При проведенні досліджень було встановлено необхідність розробки механізмів оперативного пошуку оптимізованих рішень розміщення поголів'я, його руху, розподілу виробничої площі під секції з тваринами різних технологічних груп залежно від багатоплідності свиноматок, рівня технологічного відходу, інтенсивності росту та інших зоотехнічних і виробничих показників виробництва продукції свинарства.

Спираючись на технологічні норми утримання та годівлі свиней різних технологічних груп, зоотехнічні, виробничі, цінові та ін. параметри господарської діяльності підприємств розпочато розробку таких елементів роботи комп'ютерної програми, яка повинна бути адаптована до сучасного апаратного та програмного забезпечення.

Пошук оптимальних значень зоотехнічних та виробничих показників необхідних для розробки технології потокового виробництва продукції свинарства було виконано за алгоритмом програмного засобу розробленого на мові програмування C++[7]. При використанні бібліотеки Qt, дані програмні засоби можна відкомпілювати під більшість сучасних операційних систем (Windows, Linux, Android, macOS та ін.).

Результати й обговорення. При проведенні досліджень було здійснено ряд послідовних змін значень зоотехнічних та виробничих показників для пошуку відповідності максимальної виробничої продуктивності і біологічного потенціалу свинопоголів'я, а також реальним можливостям господарства, що дозволить дотримуватись запланованих значень показників виробничого процесу.

У разі недотримання вищеназваних умов, при запуску комплексу та виходу його на заплановану потужність спостерігається порушення виробничого циклу з недоотриманням кількості приплоду або нестачі станкової і загальної площі для його розміщення, що стає причиною переущільнення поголів'я, зниження інтенсивності росту та значного збільшення технологічного відходу. Все це разом змушує інвесторів знову і знову перераховувати бізнес-плани та шукати причину появи невідповідності планованої та виконуваної виробничої діяльності.

На основі проаналізованих виробничих показників роботи провідних та середніх підприємств з виробництва продукції свинарства було знайдено орієнтири, які б могли задовольнити замовників щодо значень показників та плановану ефективність виробництва продукції свинарства.

Для проведення пошуку оптимізованих значень показників виробничого процесу комплексу потужністю 24 тис. голів відгодівлі у рік, було проведено серію розрахунків 3 
послідовною зміною значень групи зоотехнічних та технологічних показників. При проведенні розрахунків значення окремих показників були незмінними, а значення інших послідовно змінювали. Для наочності впливу зміни значень показників на необхідну кількість поголів'я, станків та загальної і станкової площі, наводимо лише 5 варіантів проведених змін значень вхідних показників.

В якості незмінних значень показників виробничого процесу було обрано семи денний крок виробничого ритму. На комплексі у виробничий процес постійно буде задіяно 1080 голів основних свиноматок, а для забезпечення процесу виявлення їх в охоті та проведення осіменіння потрібно мати 21 кнура плідника, разом з кнурами пробниками. Постійно на комплексі буде 200 холостих свиноматок, які будуть розміщені у одній секції по 11 голів у станку з площею утримання 1,7 м² на голову. Вони займатимуть 18 станків розміром 3,50×5,27 м. Для регулярного проведення ветеринарносанітарнрої очистки станків та переміщення поголів'я для проведення ветеринарних заходів необхідно мати ще 2 резервних станки. Таким чином загальна площа зайнятпа станками буде становити 377 м².

Для забезпечення крокового виробничого ритму на комплексі постійно буде утримуватись 196 умовно поросних свиноматок, які після осіменіння будуть стояти 28 днів в індивідувальних станках розміром 0,65х2,30 м, а 49 станків будуть залишатись пустими для проведення ветеринарносанітарної очистки. Таким чином для утримання умовнопоросних свиноматок потрібно мати 245 станків з загальною площею 366,3 м². Для забезпечення процесу плідного осіменіння із групи холостих потрібно вибирати по 49 голів свиноматок в охоті і осіменяти їх.

Після встановлення поросності свиноматок внаслідок прохолосту з 49 свиноматок буде залишатись по 43 свиноматки, яких і будуть переводити у групові станки розміром 3,50x4,86 м по 10 голів у станку, де їх утримуватимуть до 112 доби поросності. Всього потрібно мати 12 секцій по 4 станки у кожній, де буде постійно утримуватись 516 голів поросних свиноматок. Загалом 48 станків займатимуть загальну площу 884,5 м².

3а 5-7 днів до дати опоросу поросних свиноматок порібно переводити в індивідуальні станки для опоросу. На комплексі, на різних фразах підсисного періоду, постійно буде утримуватись 168 свиноматок, 4 групи по 42 голови.

В основу технологічних розрахунків покладено необхідність щорічного вибракування 3 причини малоплідності, низької молочності, перегулів та ін. на рівні 35 відсотків від основного маточного стада.

Також постійними показниками були: загальна тривалість репродуктивного циклу (150 днів), тривалість поросності (115 днів), тривалість холостого періоду (7 днів) та тривалість підсисного періоду (28 днів). За цих умов у господарстві впродовж року буде здійснено 52 крокових переміщень поголів'я різних технологічних груп. На одну основну свиноматку впродовж року буде отримано по 2,0..2,1 опороси, а за наявності 42 станків для утримання свиноматок з поросятами, впродовж року у господарстві буде отримано 2184 опоросів.

Підвищення інтенсивності росту поросят у підсисний період дозволить збільшити їх масу при відлученні від 8,2 до 10,4 кг, що буде впливати на рівень виручки при реалізації населенню, а отже і на прибутковість вирощування поголів'я, табл.1.

Таблиця 1

Порівняння вхідних та розрахункових даних моделювання роботи комплексу потужністю 24 тис. голів у рік

\begin{tabular}{|c|c|c|c|c|c|}
\hline \multirow{2}{*}{ Показники } & \multicolumn{5}{|c|}{ Значення даних розрахунків } \\
\hline & № 1 & № 2 & № 3 & № 4 & № 5 \\
\hline Крок виробничого ритму, днів & 7 & 7 & 7 & 7 & 7 \\
\hline Основних свиноматок, гол. & 1080 & 1080 & 1080 & 1080 & 1080 \\
\hline Кнурів-плідників та кнурів-пробників, гол. & 21 & 21 & 21 & 21 & 21 \\
\hline Технологічний відхід поросят під маткою, \% & 14.3 & 13.0 & 12.0 & 11.1 & 10.7 \\
\hline Багатоплідність, гол. & 12.0 & 12.5 & 13.0 & 13.5 & 14.0 \\
\hline $\begin{array}{l}\text { Середньодобові прирости поросят у підсисний пеірод, } \\
\text { г/добу }\end{array}$ & 230 & 230 & 250 & 280 & 300 \\
\hline Жива маса при відлученні, кг & 8.2 & 8.2 & 8.9 & 9.8 & 10.4 \\
\hline Впродовж року & & & & & \\
\hline Всього опоросів, шт. & 2184 & 2184 & 2184 & 2184 & 2184 \\
\hline Отримано приплоду, гол. & 26208 & 27300 & 28392 & 29484 & 30576 \\
\hline До відлучення залишиться, гол. & 22460 & 23751 & 24985 & 26211 & 27304 \\
\hline Реалізовано населенню (2\%) відлучених поросят, гол. & 468 & 468 & 520 & 520 & 572 \\
\hline Передано на дорощування, гол. & 21996 & 23296 & 24440 & 25688 & 26728 \\
\hline
\end{tabular}

Як видно з даних табл. 1 при одночасній зміні багатоплідності з 12 до 14 поросят і зменшенні технологічного відходу з 14,3 до 10,7\% при постійній кількості основних свиноматок впродовж року буде отримано приплоду на 4 368, а до відлучення залишиться на 4844 поросят більше відносно даних першого розрахунку. Ці зміни дозволять при тих же $2 \%$ реалізації населенню продати відлучених поросят на 104 голови більше та передати на дорощування не 21996, а 26728 голів. Також це потрібно враховувати при розрахунку необхідної кількості станків для їх розміщення.

Що стосується потреби у загальновиробничій та ста- нковій площі і кількості станків для утриманя маточного поголів'я, то рівень багатоплідності та технологічного вибракування призводить до зміни лише кількості поросят-сисунів, яких після відлучення потрібно передати на дорощування та реалізувати населенню, табл. 2.

Залежно від компактності розміщення станкового обладнання, системи гноєвидалення, способу роздачі корму та водонапування, відсоток зайнятої станками виробничої площі буде змінюватись, а отже і буде змінюватись потреба у загальній кількості приміщень для утримання поголів'я усіх технологічних груп. 
Постійне поголів'я на комплексі та потреба у станках для його розміщення

Таблиця 2

\begin{tabular}{|l|c|c|c|c|c|}
\hline \multicolumn{1}{|c|}{ Показники } & \multicolumn{5}{|c|}{ 3начення даних розрахунків } \\
\cline { 2 - 6 } & № 1 & № 2 & № 3 & № 5 \\
\hline Холостих свиноматок, гол. & 200 & 200 & 200 & 200 & 200 \\
\hline Умовно-поросних свиноматок, гол. & 196 & 196 & 196 & 196 & 196 \\
\hline Поросних свиноматок, гол. & 516 & 516 & 516 & 516 & 516 \\
\hline Підсисних свиноматок, гол. & 168 & 168 & 168 & 168 & 168 \\
\hline Поросят-сисунів, гол. & 2016 & 2100 & 2184 & 2268 & 2352 \\
\hline $\begin{array}{l}\text { Для утримання свиноматок усіх технологічних груп потрібно } \\
\text { станків, шт. }\end{array}$ & 590 & 590 & 590 & 590 & 590 \\
\hline Загальна станкова площа, м² & 3020 & 3020 & 3020 & 3020 & 3020 \\
\hline
\end{tabular}

Для утримання усіх технологічних груп свиноматок та кнурів-плідників, необхідно мати 3 приміщення довжиною 80 м та шириною 18 м (1440 м²) за умови 70\% зайнятої станками (3020 м²) загальної виробничої площі $\left(4320 \mathrm{~m}^{2}\right)$, але якщо під станки буде зайнято лише $52 \%$ загальної площі, то тоді потрібно мати 4 таких приміщення з загальною виробничою площею 5760 м².
Для проведення розрахунку потреби станків, станкової та загальної площі для розміщення поголів'я однієї крокової групи, необхідно враховувати багатоплідність свиноматок, рівень технологічного відходу у підсисний період, під час дорощування та відгодівлі, а також інтенсивність росту на всіх етапах вирощування, табл. 3.

Тривалість перебування тварин у секторі дорощування та відгодівлі залежно від рівня середньодобових приростів

\begin{tabular}{|c|c|c|c|c|c|}
\hline \multirow{2}{*}{ Показники } & \multicolumn{5}{|c|}{ Значення вхідних та розрахункових показників } \\
\hline & № 1 & № 2 & № 3 & № 4 & № 5 \\
\hline Свиноматок з приплодом, гол. & 42 & 42 & 42 & 42 & 42 \\
\hline Приплід, гол. & 504 & 525 & 546 & 567 & 588 \\
\hline До відлучення залишається, гол & 432 & 457 & 480 & 504 & 525 \\
\hline Предано на дорощування та відгодівлю, гол. & 423 & 448 & 470 & 494 & 514 \\
\hline Дорощування, днів & 70 & 63 & 56 & 49 & 49 \\
\hline Середньодобові прирости, г & 300 & 320 & 350 & 380 & 400 \\
\hline І-й етап відгодівлі, днів & 70 & 63 & 63 & 63 & 56 \\
\hline Середньодобові прирости, г & 580 & 610 & 630 & 650 & 680 \\
\hline ॥-й етап відгодівлі, днів & 56 & 56 & 56 & 49 & 49 \\
\hline Середньодобові прирости, г & 700 & 740 & 770 & 810 & 850 \\
\hline Разом, відгодівля днів & 196 & 182 & 175 & 161 & 154 \\
\hline Середньодобові прирости, г & 514 & 550 & 585 & 617 & 645 \\
\hline $\begin{array}{l}\text { Для відгодівлі тварин однієї крокової групи необхідно } \\
\text { комбікорму, тонн }\end{array}$ & 170.9 & 185.4 & 190.1 & 193.6 & 192.7 \\
\hline 3 них: стартер, тонн & 38.0 & 38.5 & 36.0 & 36.1 & 37.5 \\
\hline Гроуер, тонн & 67.8 & 69.4 & 72.7 & 76.5 & 70.8 \\
\hline Фінішер, тонн & 65.3 & 77.7 & 81.6 & 81.2 & 84.6 \\
\hline
\end{tabular}

Згідно проведених розрахунків, зміна багатоплідності свиноматок дозволить кожні 7 днів отримувати приплоду більше на 84 голови, а за рахунок підвищення збереженості у підсисний період за цей же час буде відлучено на 93 голови більше та на 91 голову більше передано на дорощування. Отже це потрібно обов'язково враховувати при плануванні розмірів секторів, кількості станків у секторі та станків для однієї крокової групи, тому що кількість поросят у кроковій групі при відлученні потребує певну кількість станків для їх розміщення, а інтенсивність їх росту визначає час перебу- вання у секторі дорощування або відгодівлі, а відповідно і кількості станків кратної кількості крокових періодів.

Підвищення середньодобових приростів на 100 г у період дорощування і на першому етапі відгодівлі та на 150 г на другому етапі відгодівлі призводить до загального зменшення періоду відгодівлі на 42 дні, що дорівнює 6 кроковим періодам. Відповідно це вплине на зміну розрахункової потреби у кількості секцій, а отже розмірів як станкової, так і загальної виробничої площі, табл. 4. 
Потреба у станках та секціях для дорощування та відгодівлі

\begin{tabular}{|l|c|c|c|c|c|}
\hline \multirow{2}{*}{ Показники } & \multicolumn{3}{|c|}{ Значення вхідних та розрахункових показників } \\
\cline { 2 - 6 } & № 1 & № 2 & № 3 & \multicolumn{2}{c|}{ № 4 5 } \\
\hline Для дорощування потрібно секцій, шт & 11 & 10 & 9 & 8 & 8 \\
\hline Зайнято секцій, шт & 10 & 9 & 8 & 7 & 7 \\
\hline Станків у 1 секції & 14 & 15 & 16 & 16 & 17 \\
\hline Станків задіяно разом, шт. & 154 & 150 & 144 & 128 & 136 \\
\hline Одночасно на дорощуванні, гол. & 4230 & 4032 & 3760 & 3458 & 3598 \\
\hline Для відгодівлі потрібно секцій, шт & 19 & 18 & 18 & 17 & 16 \\
\hline Зайнято секцій, шт. & 18 & 17 & 17 & 16 & 15 \\
\hline Станків у 1 секції & 14 & 15 & 16 & 16 & 17 \\
\hline Станків задіяно разом, шт. & 280 & 285 & 304 & 288 & 289 \\
\hline Одночасно на відгодівлі, гол. & 7914 & 7929 & 8325 & 8262 & 8096 \\
\hline Для дорощування та відгодівлі потрібно & & & & & \\
\hline Приміщень 84 х 18 м, шт & 9 & 10 & 10 & 9 & 9 \\
\hline Загальна площа, м² & 13608 & 13680 & 14400 & 13446 & 13608 \\
\hline Зайнято станками, м ${ }^{2}$ & 10164 & 10264 & 10756 & 10089 & 10215 \\
\hline Відсоток виробничої площі під станками, \% & 74.7 & 75.0 & 74.7 & 75.0 & 75.0 \\
\hline
\end{tabular}

Залежно від рівня середньодобових приростів дорощування триватиме від 10 до 7 крокових періодів, що передбачає наявність 10 або 7 ізольованих секцій для утримання поголів'я. Ще одна секція повинна бути пустою, щоб можна було проводити снітарну очистку станків після переведення поголів'я у сектор відгодівлі. Так для проведення дорощування за рахунок зміни інтенсивності росту потрібно на 18 станків менше. Хоча за рахунок збільшення приплоду потрібно більше станкової площі, але внаслідок зменшення тривалості дорощування одночасна кількість поголів'я у секторі зменшиться на 632 голови, що потрібно враховувати при визначенні кількості станків та площі приміщення, де вони будуть встановлені.

Згідно планованого рівня зоотехнічних показників, відгодівля триватиме від 18 до 15 крокових періодів, що потребує і відповідну кількість секцій для розміщення пого- лів'я кожного крокового періоду. Оскільки відбувається одночасне збільшення кількості поголів'я за рахунок підвищення багатоплідності і зменшення у секторі внаслідок підвищення рівня середньодобових приростів, то за різних розрахункових даних одночасно на відгодівлі буде перебувати від 7914 до 8325 голів, а відповідно, потреба у станках становитиме від 280 до 304 штук.

Таким чином для проведення дорощування та відгодівлі, за умови $75 \%$ зайнятої станками загальної площі приміщень, потрібно 9 або 10 приміщень з розмірами 80 х 18 м.

Після виходу комплексу на повну виробничу потужність, при незмінній кількості маточного поголів'я, щорічно буде реалізовано від 21580 до 26208 голів товарного поголів'я. Відповідно для їх годівлі потрібно планувати використання від 9691 до 11143 тонни комбікорму, табл. 5.

Таблиця 5

Кількість реалізованого поголів'я та річна потреба комбікорму після виходу комплексу на повну виробничу потужність

\begin{tabular}{|l|c|c|c|c|c|}
\hline \multicolumn{2}{|c|}{ Показники } & \multicolumn{5}{|c|}{ Значення вхідних та розрахункових показників } \\
\cline { 2 - 6 } & № 1 & № 2 & № 3 & № 4 & № 5 \\
\hline Кількість реалізованого поголів'я, голів/рік. & 21580 & 22828 & 23972 & 25168 & 26208 \\
\hline Річна потреба комбікорму, тонн & 9691.1 & 10574.4 & 10866.6 & 11142.9 & 11140.1 \\
\hline 3 них: Стартер, тонн & 1981.2 & 2010.3 & 1874.7 & 1880.8 & 1957.0 \\
\hline Гроуер, тонн & 3878.5 & 4004.5 & 4203.9 & 4421.3 & 4142.3 \\
\hline Фінішер, тонн & 3831.4 & 4559.6 & 4788.1 & 4840.8 & 5040.8 \\
\hline
\end{tabular}

При плануванні виробничої потужності комплексу з виробництва продукції свинарства, необхідно одночасно враховувати значення всіх зоотехнічних, виробничих та ін. показників, оскільки вони впливають на зміну потреби у маточному свинопоголів'ї, кількості станків та розміри секцій для розміщення тварин різних технологічних груп. Залежно від значення вхідних та розрахункових показників, у досить широкому діапазоні змінюється потреба у станках, площі для їх розміщення, комбікормах, годівницях, напувалках та багатьох інших виробничих факторах, які можна впевнено відслідкувати лише застосувавши сучасну ком'ютерну техніку.

Висновки. Розробка програмних засобів на мові програмування C++ має незаперечні переваги, оскільки дозволяє підвищити швидкодію виконання програм, використовувати сучасні стандарти та за допомогою бібліотеки Qt адаптувати розроблений програмний продукт під сучасні операційні системи.

Недотримання правил проведення розрахунків та ігнорування змінних значень вхідних даних, у кінцевому результаті призводить до порушення роботи створеного комплексу, а також невідповідності між розрахунковим бізнеспланом та реальними даними економічно-господарської діяльності підприємства з виробництва продукції свинарства.

Перспективи подальших досліджень. Свинина завжди була, $є$ і буде одним з основних харчових продуктів тваринного походження, тому попит на неї буде лише зростати. Щоб задовольнити попит, інвестори будуть шукати шляхи раціонального вкладання коштів у проведення реконструкції існуючих та побудови нових підприємств з виробництва продукції свинарства. Ефективно провести розрахунки 
з чітким визначенням вірогідних ризиків неповернення вкладених інвестицій та гарантованого забезпечення ефективної роботи підприємств, можна лише використовуючи сучасні програмні засоби які могли б бути застосовані на сучасній комп'ютерній техніці. Створення нових програмних засобів, адаптованих до сучасного апаратного та програмного забезпечення буде актуальним, оскільки проведення комп'ютерного моделювання значно прискорює виконання розрахунків, їх точність та пошук оптимальних значень, які б забезпечували прибутковість ведення господарської діяльності.

У перспективі буде здійснюватися розробка та удосконалення комп'ютерних програм, які дозволять оперативно проводити оптимізацію виробничої діяльності.

\section{Список використаної літератури:}

1. Відомчі норми технологічного проектування. Свинарські підприємства. ВНТП СГіП-46-2.95. 1995. К. 40.

2. Василенко В.Н., Третьякова О.Л., Михайлов Н.В. 2003. Методика расчетов основных производственных показателей при поточной и циклично-туровой системе опоросов. Учебное пособие. Новочеркасск. 38.

3. Волощук В.М., Замикула В.В., Підтереба О.І., Смислов С.Ю. Онищенко А.О., 2013. Інформаційні системи у прогнозуванні розвитку галузі свинарства. Свинарство. Міжвідомчий тематичний науковий збірник. Полтава. Вип. 63. 18-22.

4. Смислов С.Ю. 2012. Перехід від сезонно - турового вирощування племінного молодняку свиней на потокову технологію виробництва. Свинарство. Міжвідомчий тематичний науковий збірник. Полтава. Вип.61. 9-15.

5. Формування нормативних витрат і доходів та баланси сільськогосподарської продукції в Україні та інших країнах світу. 2003. За ред. О.М.Шпичака. К. IAE. 484.

6. Ціноутворення та нормативні витрати в сільському господарстві: теорія, методологія, практика. За ред. П.Т.Саблука, Ю.Ф.Мельника, М.В.Зубця, В.Я.Мессель-Веселяка. 2008. Т.1. С. 201-226.

7. Прата С. 2012. Язык программирования С++. Лекции и упражнения. 6-е издание. ООО "И.Д. Вильямс". 1248.

8. Макс Ш. 2015. Qt 5.3 Профессиональное программирование на С++. М.: СПб.: БХВ-Петербург. 928.

\section{References:}

1. Vidomchi normy tekhnolohichnoho proektuvannya [Departmental standards of technological design]. Svynarski pidpryyemstva. VNTP S.HiP-46-2.95. K. 1995. 40.

2. Vasylenko, V.N., Tretyakova, O.L., and Mykhaylov N.V.. 2003. Metodyka raschetov osnovnykh proyzvodstvennykh pokazateley pry potochnoy y tsyklychno-turovoy systeme oporosov [The method of calculations of the basic production indicators at the current and cyclic-tour system of farrowing]. Uchebnoe posobye. Novocherkassk, 38.

3. Voloshchuk, V.M., Zamykula, V.V., Pidtereba, O.I., Smyslov, S.Yu. and Onyshchenko, A.O., 2013. Informatsiyni systemy u prohnozuvanni rozvytku haluzi svynarstva [Information systems in predicting the development of the pig industry]. Svynarstvo. Mizhvidomchyy tematychnyy naukovyy zbirnyk. Poltava, issue 63. 18-22.

4. Smyslov, S.Yu., 2012. Perekhid vid sezonno-turovoho vyroshchuvannya pleminnoho molodnyaku svyney na potokovu tekhnolohiyu vyrobnytstva [The transition from seasonal - tour breeding pig breeding stock to streaming production technology]. Svynarstvo. Mizhvidomchyy tematychnyy naukovyy zbirnyk. Poltava. issue 61. 9-15.

5. Formuvannya normatyvnykh vytrat i dokhodiv ta balansy silskohospodarskoyi produktsiyi v Ukrayini ta inshykh krayinakh svitu [Formation of regulatory costs and income and balance of agricultural products in Ukraine and other countries of the world]. 2003. za red. O.M. Shpychaka. K.: IAE, 484.

6. Tsinoutvorennya ta normatyvni vytraty v silskomu hospodarstvi: teoriya, metodolohiya, praktyka [Pricing and regulatory costs in agriculture: theory, methodology, practice]. Za red. P.T.Sabluka, Yu.F.Melnyka, M.V.Zubtsya, V.Ya.Messel-Veselyaka. 2008. Vol. 1. C. 201-226.

7. Prata, S. 2012. Yazyk prohrammyrovanyya C++ [Programming language C ++. Lectures and exercises]. OOO "Y.D. Vylyams", 1248.

8. Maks, SH. 2015. Qt 5.3 Professyonalnoe prohrammyrovanye C++ [Professional programming C ++]. M.: SPb.: BKHVPeterburh, 928

Voloshchuk, V.M.,

Smyslov, S.Yu.,

Pidtereba, M.A,

Pidtereba, O.I.,

Khmelnychyi, L.M.

Searching the optimized solutions for the development of a project for the production of pig breeding products with a capacity of 24 thousand heads per year

The decline in pig production in the market and the constant increase in demand for it always encourage investors to look for ways to increase production of commercial pork. Increasing investor interest can only be done by assessing all levels of risk by maximizing the value of the parameters of production activity and before the start of active investment, indicating the amount of investment required and parameters of profitable activity. Searching the optimization solutions were performed by computer modeling, consistently changing parameter values to determine likely changes in production activity. It was found that with simultaneous change of multiplicity from 12 to 14 piglets and the reduction of technological waste from 14.3 to $10.7 \%$ with constant number of main sows during the year at the pig complex with a capacity of 24 thousand heads per year, the number of offspring will increase by 4368 and weaned piglets for 4844 heads, this will allow to transfer for rearing not 21996, but 26728 heads, which should be taken into account when calculating the required number of machines for their placement. Depending on the compact layout of the 
machine equipment, the manure removal system, the way of giving the feed and the water inflated, the percentage of space occupied by the machine tools will vary, and thus the need for the total number of premises to support the livestock of all technological groups will change. If the area occupied by machines is changed from 70 to 52 percent, the total area requirement will change from 4320 to $5760 \mathrm{~m}^{2}$, which is equivalent to an additional space of $80 \times 18 \mathrm{~m}$. Increasing the growth rate during the growing and fattening period reduces the need for machines and total area for livestock housing, as well as a significant reduction in the feeding time, which will reduce feed costs and accelerate machine turnover. Failure to comply with the rules for calculations and ignoring the variables of the input data eventually leads to disruption of the established complex, as well as inconsistency between the calculated business plan and the real data of economic and economic activity of enterprise on production of pig breeding products.

Key words: pig breeding, prognostication, computer modeling, change of the live-stock, machines, technological groups.

Дата надходження до редакції: 23.06.2019 р. 